\title{
BYSTANDERS IN THE SCHOOL VIOLENCE SITUATIONS FROM THE PUPIL PERSPECTIVE
}

\author{
Dita Nīmante \\ University of Latvia, Latvia \\ Baiba Moḷnika \\ University of Latvia, Latvia
}

\begin{abstract}
Bullying rarely takes place between two individuals in isolation, usually, it occurs with pupil's bystanders present. How often pupils take the role of bystander, what bystanders usually do in the bullying situation and how it can be explained was examined with 5003 pupils attending 55 Latvia's schools. Responses indicated that more than a third $(n=1913)$ of all respondents admitted that they had been in a situation where they witnessed another pupil being bullied. After analyzing the responses of those respondents, was concluded that although the majority of pupils felt bad about it, most did nothing about it or did not consider the situation important for involvement. This could be explained by the fact that the majority of children did not know what to do in the particular bullying situation. The implications for research and practice are debated.
\end{abstract}

Keywords: bullying, bystanders, pupils, Latvia.

\section{Introduction}

Violence in schools is a socially and culturally complex phenomenon that affects not only the victim and the abuser but everyone, including eyewitnesses, parents, and educators. Studies from different countries (Ferrara et al., 2019; Ribeiro et al., 2015) mention the following types of violence: psychological, physical violence, sexual violence, and bullying. Bullying includes "verbal and emotional abuse, including in the form of isolating, rejecting, ignoring insults, spreading rumours, making up lies, name-calling, ridicule, humiliation, and threats, and psychological punishment” (UNESCO, 2018). Bulling can be both verbal and physical and also, as indicated in the report "Behind the numbers: ending school violence and bullying” (UNESCO, 2019), take place in cyberspace. The report mentions physical disabilities, gender, social inequality, ethnic, linguistic, and cultural diversity, and gender identity as causes of bullying and 
violence in schools. Compared to other OECD - PISA participating countries and economies, the percentage of students in Latvia who reported being bullied (includes any type of bullying act) at least a few times a month is one of the highest. In Latvia, 35.5\% of fifteen-year-old students suffer from school violence at least a few times a month (on average in OECD countries - 23\%) (PISA, 2018b). Compared to the previous study (PISA, 2015), the level of violence has increased both in Latvia and on average also in OECD countries. Students in Latvia are one of the less co-operative, compared to other PISA-participating countries and economies (PISA, 2018a).

As it has been defined by several authors (Olweus, 2010; Peguero et al., 2018, O’Brien, 2019), bullying is a specific type of aggressive behaviour, which is characterized by the unequal power relationship between the abuser and the victim, it is systematic abuse (not a single episode of violence) and has a certain intension. Primarily in bullying situations, the perpetrator and the victim are those, who are in the focus and it is very important to identify them and act accordingly (Stephen \& Harphold, 1999; Dewey et al., 2004; Mudhovozi, 2017). Evaluation of the KiVa antibullying program (Yang \& Salmivalli, 2015) gives certain characteristics of bullies and victims. Bullies are usually aggressive, highly emotional, and hyperactive. Victims constantly have problems with selfdefinition, they often think negatively about themselves and others. It also appears that both - victims and bullies - have a lack of social and performance skills, comparing with their peers. Having considered the social context as one of the most important factors in forming the bullying situations in schools (Graham, 2016; Rigby, 2014) the focus from perceiving the bullying as relations between two individuals (perpetrator and victim) move towards the perception of bullying as the process which involves and is influenced by peers (UNESCO, 2018). The actions, behaviors, and attitudes of bystanders, can both - increase and reduce the level of bullying. (Monks et al., 2009; Salimi et al., 2020). Olweus (1993) and Salmivalli (2014) give a wide spectrum of roles, which adolescents could take during bullying situations, ranking from bully supporters to defenders of victims. However, the proportion of those, who are present in the situation, but not taking an active role, forms the largest part of the bullying cycle (Twemlow et al., 2004).

Several studies on the topic of violence have been implemented in Latvia, also specifically on school violence (TNS Latvija, 2015, Jozauska, 2018, LindeOzola, 2019, SKDS, 2020). Authors of research commissioned by both governmental and non-governmental organizations have focused on topics such as the prevalence of violence, bullying, forms of violence, causes of violence, bullying. Jozauska (2018) explored teacher's necessary competencies in violence prevention. Although the role of bystanders has been analysed in research in the world, it has not been analysed in Latvia so far. Thus, this study focuses on bystanders in the bullying situation. In Latvia there are used several terms to 
describe the same phenomena of bullying, for example, school violence, mobbing, bullying, mockery, we will use the term bullying as the prolonged naming, beating, emotional humiliation, or another kind of emotional abuse. This is usually done by several peers uniting against someone weaker or by one person. This study describes general trends in answering the questions: How often do pupils take the role of bystander and what bystanders usually do in the bullying situation, how can it be explained?

\section{Method}

The quantitative approach was used to examine the research questions. The original survey has been created (Children's bullying experience at school) by the social project "Neklusē" ([Speak out] (https://nekluse.lv/) with 39 questions. There is a diverse structure of items offered for the answers, which have to be chosen: (a) with different options for the answers at the same time, and those options are varying from 1 to 8 , (b) with one possible answer from more options offered, in this case, the overall sum of the options makes $100 \%$. In order to analyse in detail, the role of bystanders, a question was asked: have you been experiencing situations in school where someone was being hurt by another pupil or pupils? If the pupils answered in the affirmative, then 6 questions were followed: what kind of bullying did you see, how often have you seen someone being hurt by others, how did you feel about it (when you saw someone being hurt by others), what were you doing when you saw bullying, what happened when you got involved, why you were not involved? The question: "Do you know what is bullying?" also was analysed.

The questioner was distributed out to 55 Latvia's schools through EDURIO platform and data were collected by EDURIO ltd (https://home.edurio.com/) in the 2019 and 2020 school year. 5014 pupils participated in the research, but 5003 pupil's responses have to be analyzed as they were fully completed.

The respondents represent all 5 regions of Latvia: Riga, Vidzeme (18\%), Zemgale (19\%), Latgale, Kurzeme (15\%). Almost half of the respondents were from the Riga region (49\%), the smallest part from Latgale (only 9 respondents). Secondary (62\%), primary [pamatskola - in Latvian] (35\%) and pre-primary (3\%) schools are represented in the survey. Students from the 1st grade to the 12th grade participated in the survey. The majority of respondents were from grades $4,5,6$, $7,8,9$, and 10 representing $89 \%$ of the all respondents.

During the survey 1913 out of 5003 pupils (39\%) indicated that they have been experiencing situations in school where someone was being hurt by another pupil or pupils. Therefore, the current study focus on these students. The profile of those 1913 respondents was almost the same as previously described. Respondents represent all 5 regions (Riga (49\%), Vidzeme (18\%), Zemgale 
(18\%), Latgale (less than 1\%), Kurzeme (15\%), the majority of pupils were learning in secondary school (62\%), but $25 \%$ in primary school. The majority of respondents were from grades $4,5,6,7,8,9$, and 10 representing $89 \%$ of all respondents (see Figure 1).

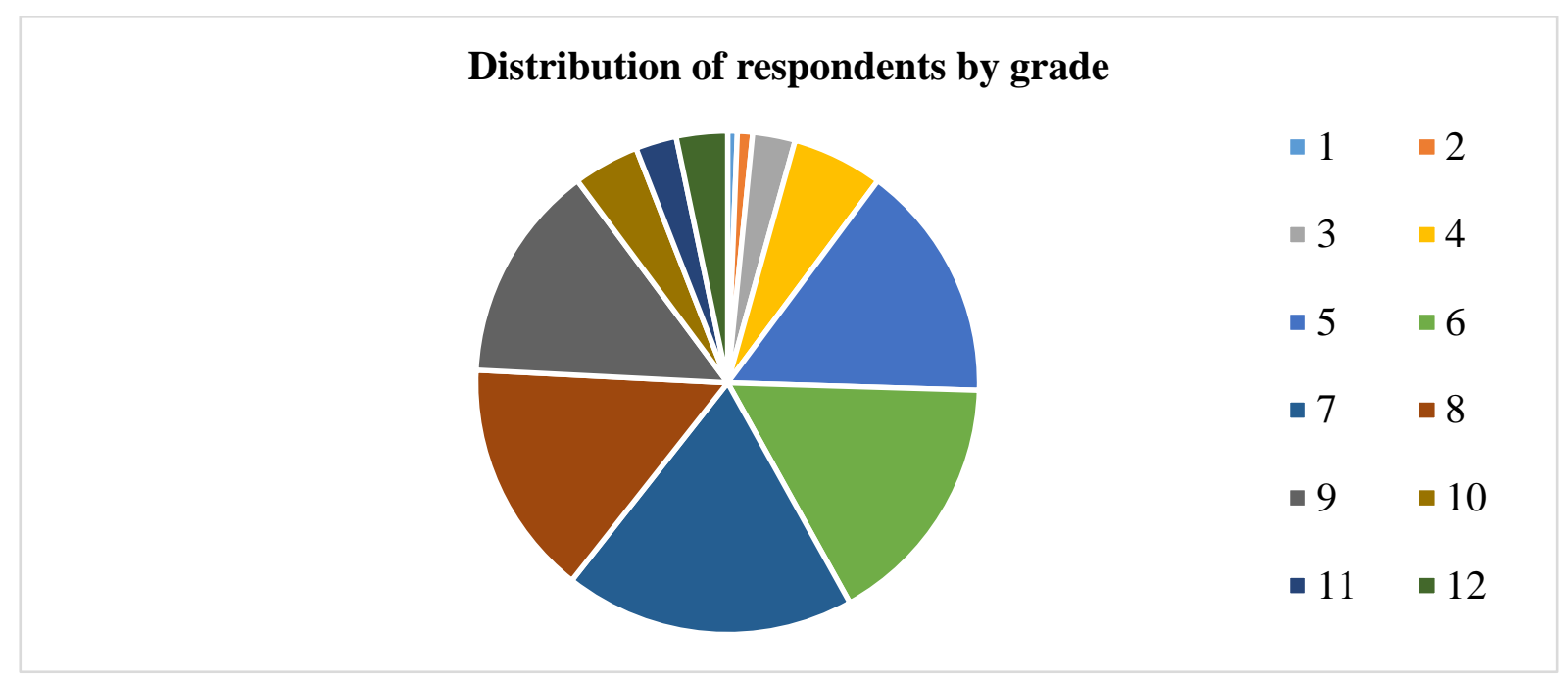

Figure 1 Distribution of Respondents by Grade

It means that the majority of respondents were adolescents from age 10/11 up to $16 / 17$ years of age.

In processing the data gained from the answers the methods of descriptive statistics were used. Most often the data were presented in illustrative graphs of absolute and/or relative frequencies.

\section{Theoretical Background}

Research (Monks et al., 2009; Salmivalli, 2014; Maunder, Crafter, 2018) shows, that bullying mainly forms in peer groups, and roles, which involved persons hold, may change over time. Salmivalli (2014) lists the roles of participants that can be taken up by bystanders in the bullying process: assistants can join the bullying act and assist the bully; reinforcers - can encourage the bully by reacting positively to what is happening; outsiders - believes that it is better not to interfere in the bullying situation and stays neutral; Salmivalli (2014) also stresses, that outsiders should be called silent approvers. It is necessary to mention, that in the case of a bullying situation the neutrality doesn't mean noninvolvement. Defenders - trying to intervene and defend the victim. Research (Volk et al., 2015; Graham, 2016) shows that victims who have friends could overcome bullying situations in an easier way and could defend their positions better. 
O’Connell et al. (1999) consider bystander intervention to be crucial. In up to $50 \%$ of cases, bullying can be stopped by peer interference. At the same time Salmivalli \& Voetenen (2004) explain that bystanders did not intervene because they did not want to be the next victims, in most cases, they are also not aware that non-interference is a kind of support to the bully. Casey et al. (2016) agree, that the fear of being the next victim can be mentioned as one of the barriers to why the intervention does not take place also The qualitative research, involving 113 American young people (14-18) showed, that other barriers for intervention are unwillingness to interfere in other people affairs, and finally the notion that bystander's advice may be underestimated. At the same time, the research reveals, that those, who are more likely to intervene are ones, who had a personal experience of being victimized or can wear "other shoes" or a higher level of empathy. Another research (Walter, Espelage, 2019), where 764 American adolescents (372 boys, 392 girls) were taken, also proved a link between affective - emotional empathy and the bystanders' intervention, but no link was found with cognitive empathy, ability to understand another person's feelings without getting emotionally involved. Research (O’Connel et al., 1999), where 5,000 Canadian children and adolescents (ages 5-14) were involved found out, that students' willingness to help victims decreased with age. A similar conclusion comes out also from research, what was done in Australia (Rigby, Slee 1991) the emotional desire to defend the victim decreases by the age of 12 . There is a difference between, what children think they should do in bullying situations and what they do to intervene.

Data from the research (O'Connel et al., 1999) shows, that $83 \%$ of 5000 observed children and adolescents felt uncomfortable when seeing bullying situation, but $41 \%$ of them intervene, even more - only $11 \%$ responded, that other peer trying to intervene. There is a certain necessity to empower bystanders and to clear their role. Observing the strategies, that children generally use for intervention - direct verbal confrontation; direct physical confrontation; distraction; indirect intervention and passive (Casey et al., 2016). Salmivalli (2014) recommends empowering children with strategies for dealing with bullying situations. Video films, stories, as well as role-plays could be useful tools to model the situation, by taking up different roles and to get a better awareness of the victim's feelings. Combining problem-solving methods in groups with a theory of group dynamics could serve, that the bullying process can be understood both emotionally and cognitively (O’Connel et al.,1999). Strengthening of empathy leads to the strengthening of the motivation to intervene and builds up an awareness, that bystanders in bullying situations are also responsible for the solution of the situation. Bullying should be formulated as a problem that affects everyone involved, regardless of their role (O’Connel et al., 1999; Salmivalli, 2014). The school is a great place to work with a group, but a school-wide 
approach is needed (Storer et al., 2017). Bullying intervention programs mostly focus on teachers, their training, their capacity to deal with situations, but it is essential to share responsibility for its implementation with children and adolescents, to raise their awareness, that they are part of the solution instead of part of the problem, what should be solved by adults (Storer et al., 2017). The reason, why bystander intervention programs are so difficult to design and implement, could be the necessity to promote the system, that the solutions, how to handle with bullying situation come from the side of children, they need to change their attitude and behavior towards their peers. The evaluation of the effectiveness of the anti-bullying program KiVA (Yang, Salmivalli, 2015), proves, that a change in peer attitudes and reaction is influential and the bystanders' role could be the determinant factor for bullying to be continued or stopped.

\section{Results}

To answer the first research question: how often pupils take the role of the bystander, there were analysed the question: have you been experiencing situations in school where someone was being hurt by another pupil or pupils? It was identified, that more than third (39\%) of pupils $(n=1913$ out of $n=5003$ ) indicated, that they have been experiencing situations in school, where someone was being hurt by other pupil or pupils. It is important to mention, that $93 \%$ of those students were aware of what bullying meant exactly (73\%) or partially (20\%).

Two more questions were analysed: "How often have you seen someone being hurt by others?" and "What kind of bullying did you see?"

Answering the question "How often have you seen someone being hurt by others?" students were able to provide answers: 1- daily, 2-several times a week, 3- once a week, 4-once a month, 5-once in the last 6 months, 6-once in the last 12 months. Pupils' responses show, that most pupils have witness bullying at least once a week and more (49\%) (See Figure 2).

Answering the question, "What kind of bullying was used?", it could be concluded that students most often saw emotional abuse (75\%), including social ignorance and exclusion (36\%), physical abuse was mentioned in $40 \%$ of cases. $31 \%$ of students said that bullying was witnessed on social networks or in some other cyber form.

To answer the second research question "what bystanders usually do in the bullying situation, how it can be explained" the following questions were focused: "How did you feel about it (when you saw someone being hurt by others)?" "What were you doing when you saw bullying?" "What happened when you got involved?" "Why you were not involved?" 


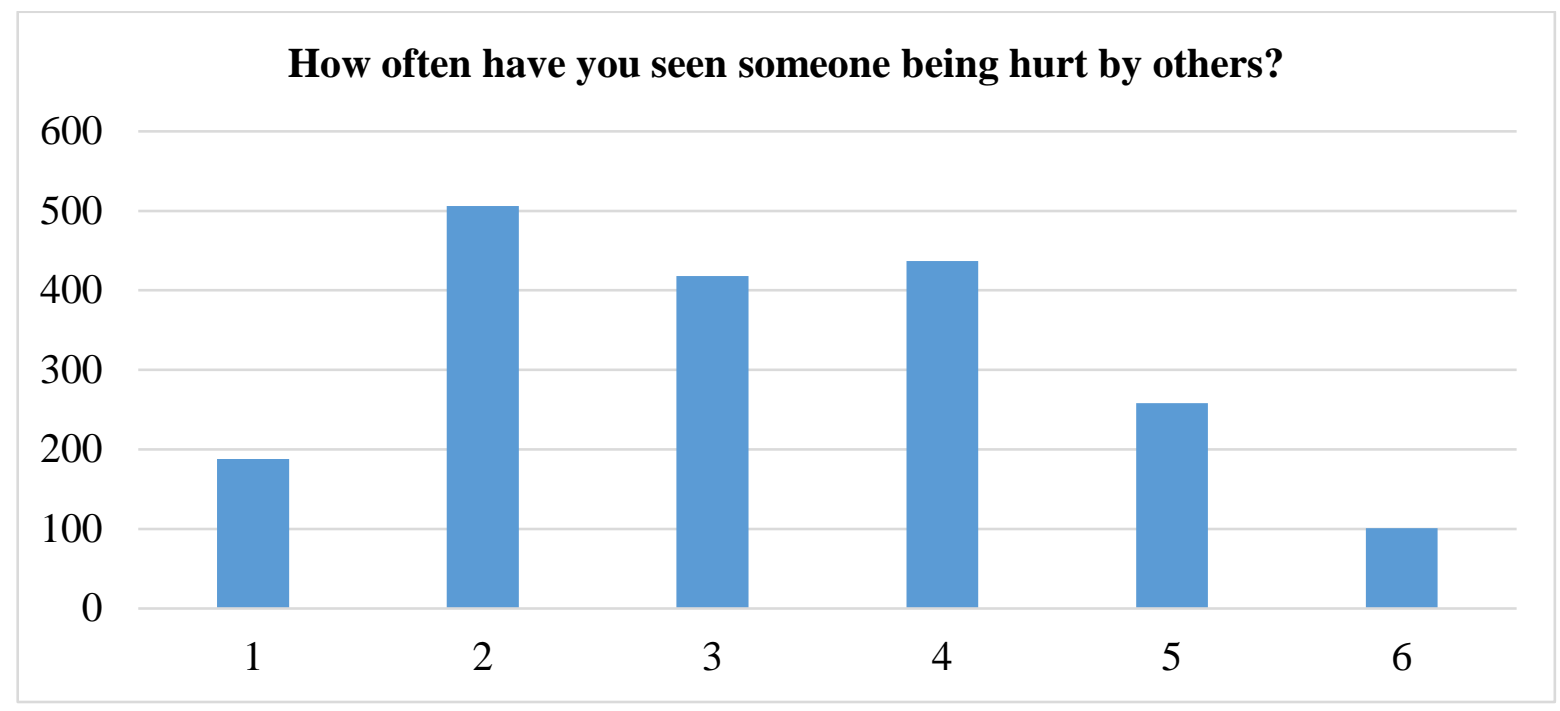

Figure 2 How Often Have You Seen Someone Being Hurt by Others?

To the question, "How did you feel about it (when you saw someone hurt others)"? most students answered that they feel bad (62\%) or sad (20\%) about it. It is in line with other research where $83 \%$ of respondents felt uncomfortable when seeing bullying situations (O’Connel et al., 1999). Although the children felt this way, the majority (49\%) admitted that they did nothing, most probably taking up the role of an outsider (Salmivalli, 2014) in this bullying situation. 42\% of students admitted that they tried to help a student who had suffered, probably taking up the role of a defender (Graham, 2016). 24\% noted that they informed adults about bullying, which is also explained by taking up the role of a defender (Salmivalli et al., 1997). 3\% of pupils admitted that they have joined the bully, thus taking the role of assistant (Salmivalli, 2014).

To the question "What happened when you got involved?" $42 \%$ of pupils answered that they felt good about it. 34\% admitted that as the result of involvement the bullying was stopped. $30 \%$ responded that other people were involved as the result. Unfortunately, $10 \%$ of pupils admitted that after involvement they became a victim of a bully. The last question asked to describe: "Why did you wasn't involved?" The majority of students answered, that they did not know what to do (48\%). 31\% of pupils assessed the situation as not serious enough to be involved in it. $21 \%$ of pupils were afraid, that they will become the next victims, so they better choose not to be involved. This is in line with previous research and it explains that bystanders did not intervene because they did not want to be the next victims (Salmivalli, Voeten, 2004). 16\% of pupils answered that other people appreciated the involvement. $18 \%$ of pupils admitted that they did not care at all about the situation. 


\section{Conclusions and Discussions}

Bullying rarely takes place between two individuals in isolation, usually, it occurs with pupil's bystanders present. The current research indicates that more than a third of all pupils admitted that they had been in a situation where they witnessed another pupil being bullied. Although the majority of pupils felt bad about it, most did nothing or did not consider the situation important for involvement. The results are in line with previously conducted research elsewhere (O’Connel et al., 1999). This may be explained by the fact that the majority of children did not know what to do in a particular bullying situation or may have a high tolerance to the bullying, as they did not consider the situation serious. Previous research that has been conducted in Latvia concluded, that there is a high level of tolerance towards violence in society (SKDS, 2020), however, it is relatively lower in educational institutions. Young people perceive that violence is an integral part of school life even though young people are increasingly more often able to recognize violence if compare with other parts of the population (SKDS, 2020).

This leads to the idea that it is a certain necessity to empower bystanders and to clear their role in the bullying situation. The pedagogical intervention programs for bystanders in a bullying situation is considered to be as important as programs for the bullies and their victims to reduce the bullying (Fair, Florell, 2019). There can be used different new pedagogical approaches and interventions to help pupils to understand their roles in bullying and to interfere, for example drama method and story writing (Goodwin et al., 2019, Barnett et al., 2019). As it is admitted by previous research, bystanders' responses to bullying can influence bullying occurrence and effects. Non-interference does not mean neutrality - in the case of bystanders, it is tacit support for the bully. Current research in line with previous research (Salmivalli et al., 1997, Salmivalli, Voeten, 2004) proved that bystanders take up different roles in the bullying situation - outsiders, defenders, and assistants. In the current research the majority of bystanders admitted that they take up the role of defenders and outsiders, the smallest part takes up the role of assistant of a bully. The results are inconsistent with international research (Salmivalli et al., 1997), therefore there is a need for further studies to specify the roles of bystanders in the bullying situation, by making the research instrument more specific (Bistrong et al., 2019).

\section{References}

Barnett, J.E.H., Fisher, K.W., O’Connell, N., Franco, K. (2019). Promoting upstander behavior to address bullying in schools. Middle School Journal, 50 (1), 6-11. 
Bistrong, E., Bottiani J.H., Bradshaw, C.P. (2019). Youth Reactions to Bullying: Exploring the Factors Associated with Students' Willingness to Intervene. Journal of School Violence, 18 (4), 522- 535.

Casey, E.A., Lindhorst, T., Storer, H.L. (2016). The Situational-Cognitive Model of Adolescent Bystander Behavior: Modeling Bystander Decision-Making in the Context of Bullying and Teen Dating Violence. Psychology of Violence, 7(1).

Dewey, G., Cornell, Ph.D., Brockenbrough, K. (2004). Identification of Bullies and Victims. Journal of School Violence, Nr3, 63-87.

Fair, G., Florell, D. (2019). Bullying, bystanders, and books. Middle School Journal, 50(1), 12-23.

Ferrara, P., Franceschini, G., Villani, A. (2019). Physical, psychological, and social impact of school violence on children. Italian Journal of Pediatrics, Nr.45.

Graham, S. (2016). Victims of Bullying in Schools. Theory into Practice, 55(2), 136-144.

Goodwin, J., Bradley, S.K., Donohoe, P., Queen, K., O’Shea, M., Horgan, A. (2019). Bullying in Schools: An Evaluation of the Use of Drama in Bullying Prevention. Journal of Creativity in Mental Health, 14 (3), 329-342.

Jozauska, K. (2018). Skolotāju kompetence vardarbības pret bērnu novēršanā. Izglītība zinātnei un praksei, Vulāne, A.Stikute, E. (Eds). LU Pedagoǵijas, psihologijas un mākslas fakultāte Skolotāju izglītības nodaḷa. Rīga: LU Akadēmiskais apgāds.

Linde-Ozola, Z. (2019). Pārskats par programmām seksuālās vardarbības pret bērnu prevencijā Latvijāa. Latvijas Universitāte. Retrieved from: https://centrsdardedze.lv/ data/petijumi/parskats-par-prevences-pasakumiem.pdf

Maunder, R., Crafter, S. (2018). School bullying from a sociocultural perspective. Aggression and Violent Behavior, 38, 13-20.

Monks, C.P., Smith, P.K., Naylor, P., Barter, C., Ireland, J.L., Coyne, L. (2009). Bullying in different contexts: Commonalities, differences and the role of theory. Aggression and violent behavior, 5 .

Mudhovozi, P. (2017). Bullies and Victims at a Public Secondary School: The Teachers' Perspective. International Journal of Educational Sciences, Nr10, 115-121.

O’Brien, N. (2019). Understanding alternative bullying perspectives through research engagement with young people. Frontiers in Psychology, N3, 34-37.

O'Connell, P., Pepler, D., Craig, W. (1999). Peer involvement in bullying: insights and challenges for intervention. J Adolesc, 22(4), 437-452.

Olweus, D.A. (2010). Bullying in schools: facts and intervention. Kriminalistik, 64(6), 28-32.

Olweus, D. (1993). Social Withdrawal, Inhibition, and Shyness in Childhood. Psychology Press, Nr8, 315-341.

Peguero, A.A, Connell N.M, Hong J.S (2018). Introduction to the Special Issue "School Violence and Safety.” Youth Violence and Juvenile Justice, 16(2),119-123.

PISA. (2015). Students Wellbeing. Volume III. OECD iLibrary. Retrieved from: https://www.oecd-ilibrary.org/docserver/9789264273856-en.pdf?expires=1615297206\& id=id\&accname $=$ guest $\&$ checksum=E1465FA6D323C9189BA847E0F3EB1EBD

PISA. (2018a). Latvia Student performance (PISA 2018). OECD Library. Retrieved from: https://gpseducation.oecd.org/CountryProfile?primaryCountry=LVA\&treshold=10\&top ic $=$ PI

PISA. (2018b). The Programme for International Student Assessment (PISA). Results from PISA. OECD library. Retrieved from: https://www.oecd.org/pisa/ publications/PISA2018_CN_LVA.pdf 
Ribeiro, I.M., Ribeiro,P., Teixeira,A.S Pratesi,R., Gandolfi L. (2015). Prevalence of various forms of violence among school students. Acta Paulista de Enfermagem, 28(1), 54-59.

Rigby, K., Slee, P.T. (1991). Bullying among Australian School Children: Reported Behavior and Attitudes toward Victims. The Journal of Social Psychology 131(5):615-27.

Rigby, K. (2014). How teachers address cases of bullying in schools: a comparison of five reactive approaches. Educational Psychology in Practice, 30(4), 409-419.

Salimi, N., Karimi-Shahanjarin, A., Rezapur-Shahkolai, F., Hamzeh, B., Roshanaei, G., Babamiri, M. (2020). Use of a Mixed-Methods Approach to Evaluate the Implementation of Violence and Bullying Prevention Programs in Schools. Education and Urban Society.

Salmivalli, C. (2014). Participant roles in bullying: How can peer bystanders be utilized in interventions? Theory Into Practice, 53(4), 286-292.

Salmivalli, C., Voeten, R. (2004). Connections between attitudes, group norms, and behavior in bullying situations. International Journal of Behavioral Development, 28(3), 246-258.

Salmivalli, C., Huttunen, A., \& Lagerspetz, K. M. (1997). Peer networks and bullying in schools. Scandinavian Journal of Psychology, 38(4), 305-312. doi:10.1111/14679450.00040

SKDS. (2020). Stiprinot gimenes, kopienas un attiecības: antropologiska pieeja vardarbības izpētē. Retrieved from: https://www.antropologija.lu.lv/fileadmin/user_upload/ lu_portal/projekti/antropologija/Vardarbibas_pieredze_fin.pdf

Stephen, R., Harphold, J.A. (1999). School Violence: Lessons Learned. FBI Law Enforcement Bulletin, 68 (9), 9-16.

Storer, H.L., Casey, E.A., Herrenkohl, T.I. (2017). Developing “whole school” bystander interventions: The role of school-settings in influencing adolescents responses to dating violence and bullying. Children and Youth Services Review, 74, 87-95.

Twemlow, S.W., Fonagy, P., Sacco, F.C. (2004). The role of the bystander in the social architecture of bullying and violence in schools and communities. Ann N Y Acad Sci, 1036, 215-232.

TNS Latvija. (2015). Tiesībsarga pētījums par vardarbības izplatību pret bērniem Latvijā. Retrieved from: https://www.tiesibsargs.lv/uploads/content/legacy/4239_TNS_ Vardarbibas_pret_berniem_izplatiba_Latvija_2015.pdf

UNESCO. (2018). School violence and bullying: Global status and trends, drivers and consequences. United Nations Educational, scientific, and cultural organization. Retrieved from: http://www.infocoponline.es/pdf/BULLYING.pdf

UNESCO. (2019). Behind the numbers: ending school violence and bullying. United Nations Educational, scientific, and cultural organization. UNESCO. Retrieved from: https://unesdoc.unesco.org/ark:/48223/pf0000366483

Volk, A.A., Dane, A.V., Marini, Z.A., Vaillancourt, A. (2015). Adolescent Bullying, Dating, and Mating: Testing an Evolutionary Hypothesis. Evolutionary Psychology, 13 (4).

Walter, G.D., Espelage, D.L. (2019). Cognitive/Affective Empathy, Pro-Bullying Beliefs, and Willingness to Intervene on Behalf of a Bullied Peer. Youth \& Society, Nr4, 161-163.

Yang, A., Salmivalli, C. (2015). Effectiveness of the KiVa antibullying programme on bullyvictims, bullies, and victims. Educational Research, 57(1), 80-90. 